\title{
DZIEDZICTWO EUCHARYSTYCZNE FRANCISZKANÓW KRAKOWSKICH OD XIII DO XV WIEKU
}

Niniejszy zarys powstał z przygotowania do dwu wydarzeń w roku 1987. Pierwszym z nich był Kongres Eucharystyczny z udziałem papieża Jana Pawła II, drugim natomiast 750-lecie przybycia do Krakowa Braci Mniejszych św. Franciszka z Asyżu. Stąd temat eucharystyczno-franciszkański, zawężony czasowo do średniowiecznego okresu działalności franciszkanów w Krakowie, na tle charyzmatu założyciela i wczesnej tradycji doktrynalno-apostolskiej w zakonie minorytów. Temat jest wprawdzie historyczny, ale ma wydźwięk aktualizujący, mianowicie dotyczy cennego dziedzictwa duchowego, jakie od początku, bez przerwy aż do naszych dni, pielęgnował z różnym nasileniem klasztor św. Franciszka z Asyżu w Krakowie. Jest więc jego zwrotem do własnych korzeni, zgodnie z zaleceniem Soboru Watykańskiego II, wytyczającym drogę odnowy ${ }^{1}$.

\section{EUCHARYSTYCZNY CHARYZMAT ŚW. FRANCISZKA Z ASYŻU}

Ostatnie dziesiątki lat wieku XII i pierwsze wieku XIII były okresem poważnych rozbieżności doktrynalnych w stosunku do Eucharystii. Jeszcze nie wygasła całkowicie herezja Berengariusza, podważająca realną obecność Jezusa Chrystusa pod konsekrowanymi postaciami, a już szerzyły się błędy patarenów i katarów, odmawiających kapłanom niegodnym władzy sprawowania Eucharystii. Błędom doktrynalnym towarzyszyła wielka ignorancja tajemnicy Eucharystii, sprzyjająca przesądom, żądzy nadzwyczajności, brakowi szacunku dla Chrystusa eucharystycznego i karygodnym zaniedbaniom. Np. w Asyżu dnia 6 grudnia dzieci wybierały prowodyra, który na czele ich orszaku wkraczał niby biskup do kościoła św. Mikołaja i przewodził zabawie, inicjując farsy, gry i tańce, do których mieszały się męty miejskie. Te dziecięce juwenalia kończyły się wielką ucztą dopiero w dniu Młodzianków².

${ }^{1}$ Dekret Perfectae caritatis, nr 2.

${ }^{2}$ A. Fortin i, Nova vita di San Francesco, t. 1, Assisi 1959, s. 121. 
Dokumenty $\mathrm{z}$ tamtych czasów wyliczają zaniedbania duchownych, np. list inkwizytora $\mathrm{z}$ Passau ${ }^{3}$ :

Duchowni, do których należała troska o Najświętszy Sakrament, zaniedbywali odnawiania świętych postaci; dopuszczali, by zestarzałe komunikanty walały się po ziemi; Najśw. Sakrament przechowywali w swoich mieszkaniach; przy noszeniu Wiatyku do chorych wstępowali po drodze do szynków na napitek; bywało, że Komunii św. udzielali publicznym grzesznikom, a odmawiali jej ludziom naprawdę godnym; Mszę św. przewlekali niezmiernie długimi i hałaśliwymi śpiewami; w kościołach urządzali handel napojami.

W tej atmosferze łatwo znajdowały posłuch religijne nowinki, zaprzeczające realnej obecności Chrystusa w Sakramencie ołtarza, wyśmiewające publiczną adorację Najświętszego Sakramentu czy odmawiające ważności konsekracji, dokonywanej przez kapłanów grzesznych. Kościół usiłował przeciwdziałać powstałemu kryzysowi. Teologowie uściślali terminologię sakramentalną i eucharystyczną, opracowywali odnośne zagadnienia doktrynalne w drodze do wielkich syntez scholastycznych. Głos zabierały synody partykularne, a wreszcie Sobór Laterański IV w r. 1215 potwierdził wiarę w realną obecność Chrystusa w Eucharystii, wprowadził termin: transsubstantiatio przeistoczenie, na oznaczenie sposobu tejże obecności, ustanowił przykazanie o spowiedzi przynajmniej raz w roku i o Komunii św. wielkanocnej, nakazał przechowywanie Najświętszego Sakramentu pod kluczem i przenoszenie go w stroju liturgicznym, ze światłem i dzwonkiem ${ }^{4}$.

Wielkim realizatorem uchwał soboru Laterańskiego IV stał się niebawem św. Franciszek z Asyżu i jego trzy zakony. Brat Tomasz z Celano, świadek życia i nauczania św. Franciszka, pisat ${ }^{5}$ :

Żarem całego serca płonął względem sakramentu Ciała Pańskiego, jak najbardziej zdumiewając się nad tą drogą łaską i najżyczliwszą miłością. Zaniedbanie wysłuchania codziennie przynajmniej jednej Mszy uważał za niemałą zniewagę. Często komunikował i to tak nabożnie, że swą pobożnością wpływał na innych. Otaczając ten czcigodny Sakrament wszelkim uszanowaniem, składał w ofierze wszystkie swe członki, a przyjmując niepokalanego Baranka, spalał swego ducha w ogniu, który zawsze płonął w nim na ołtarzu serca.

Swiadectwo Celańczyka potwierdził św. Bonawentura w swojej Legenda maior ${ }^{6}$ :

Wobec sakramentu Ciała Pańskiego płonął wielkim żarem miłości całą swą istotą, podziwiając w największym zdumieniu ową najdroższą laskę oddania się i najszczodrobliwszą miłość. Często przystępował do Komunii św. i to tak pobożnie, że sprawial, iż inni stawali się pobożni, a zakosztowawszy słodyczy Niepokalanego Baranka, jakby upojony w duchu, bardzo często wpadał w zachwyt.

Cześć św. Franciszka dla Najświętszego Sakramentu, zaznaczona przez obydwu urzędowych biografów - Tomasza i Bonawenturę, o wiele szerzej

${ }^{3}$ T. Desbonnets, D. Vorreux, Saint François d'Assise. Documents, Paris 1969, s. 125 (nota 5). s. 262.

${ }^{4}$ S.J. Piat, Saint François d'Assise à la découverte du Christ pauvre et crucifié, Paris 1968,

${ }_{5}^{5}$ Wczesne źródta franciszkańskie, t. 1, Warszawa 1981, s. 181 (2 Cel, nr 201).

${ }^{6}$ Tamże, s. 279. 
i wyraźniej wynika z własnych pism Franciszka. Znajdujemy w nich wszystkie główne aspekty Eucharystii, aktualne wówczas w teologii i w życiu chrześcijańskim.

\section{Ustanowienie Eucharystii}

„Blisko przed męką Jezus sprawował paschę ze swoimi uczniami i wziąwszy chleb, dzięki czynił i błogosławił i łamał mówiąc: Bierzcie i jedzcie, to jest Ciało moje. I wziąwszy kielich powiedzial: To jest Krew moja nowego przymierza, która za was i za wielu będzie wylana na odpuszczenie grzechów"7. Łatwo zauważyć, że tekst Franciszkowy jest najbardziej zbliżony do opisu św. Mateucza (Mt 26, 26-28). Można stąd wnosić, że Franciszkowi chodziło o powołanie się na Mateusza jako naocznego świadka misterium eucharystycznego w Wieczerniku $^{8}$.

\section{Rzeczywista obecność Jezusa w Eucharystii i sposób widzenia Go w niej}

„Otóż uniża się co dzień jak wtedy, gdy z tronu królewskiego zstąpił do łona Dziewicy. Codziennie przychodzi do nas w pokornej postaci. Co dzień zstępuje z łona Ojca na ołtarz w rękach kapłana. I jak ukazał się świętym apostołom w rzeczywistym ciele, tak i teraz ukazuje się nam w świętym Chlebie. I jak oni swoim wzrokiem cielesnym widzieli tylko Jego Ciało, lecz wierzyli, że jest Bogiem, ponieważ oglądali Go oczyma ducha, tak i my, widząc chleb i wino oczyma cielesnymi, starajmy się dostrzegać i wierzmy mocno, że jest to Jego żywe i prawdziwe najśw. Ciało i Krew. I w taki sposób Pan jest zawsze ze swymi wiernymi, jak sam mówi: Oto Ja jestem z wami aż do skończenia świata"9. Są to jedne z najpiękniejszych, a zarazem najgłębszych myśli, jakie kiedykolwiek zostały wypowiedziane i zapisane o realnej obecności Jezusa w Eucharystii.

Sw. Franciszek nie traktuje jednak Eucharystii jako samej dla siebie, ani nawet jako tylko przedmiotu adoracji. Eucharystia jest dla niego pokarmem, bo Pan powiedział: „Kto pożywa Ciało moje i pije Krew moją, ma życie wieczne (J 6,55). Stąd Duch Pański, przebywający w wiernych swoich, jest tym, który przyjmuje najśw. Ciało i Krew Pana"10. Mamy tu nawiązanie do św. Pawła Ap.: „Swiątynią Boga jesteście i Duch Boży w was mieszka” (1 Kor 3,16). Franciszek podkreśla rolę Ducha Świętego w patrzeniu na Eucharystię i w jej 169.

7 2. List do wiernych, w. 6-7, [w:] Pisma św. Franciszka z Asyżu, Warszawa 1982, s. 168

${ }^{8}$ E. Fra nceschi n i, L'Eucarestia negli scritti di San Francesco, [w:] Quaderni di spiritualità francescana, z. 3: L'Eucarestia, Assisi 1962, s. 40.

${ }^{9}$ Napomnienie 1, w. 16-22, [w:] Pisma..., s. 36-37.

${ }^{10}$ Tamże, w. 11-12. 
przyjmowaniu, albowiem wiara w obecność Jezusa pod postaciami jest dzielem Ducha i tak samo godne Go przyjmowanie. Innymi słowy, podczas Komunii św. dokonuje się w nas spotkanie Chrystusa, prawdziwego Boga i prawdziwego Człowieka, z Duchem Świętym. Zatem tylko ten człowiek godnie przyjmuje Jezusa w Komunii, w którym mieszka Duch Boży. „Wszyscy inni, którzy nie mają udziału w Duchu, a ośmielają się przyjmować Ciało i Krew Pana, sąd sobie jedzą i piją"11. Dla Franciszka charakterystyczny jest zwrot: posiadanie Ducha Pańskiego. Wyraża on ścisłe zjednoczenie człowieka z Duchem Świętym, przy czym działanie Ducha Pańskiego jest dwojakie: oczyszczające skażoną naturę, czyli „ciało” z grzechów, wad i skłonności do grzechu, oraz oświecające i jednoczące z Bogiem, co dzieje się właśnie przez Eucharystię. Duch Pański bowiem udziela ludziom duchowym niezachwianej wiary w Bóstwo Chrystusa eucharystycznego i pozwala im godnie i owocnie przyjmować Ciało i Krew Pana $^{12}$.

\section{Sposób konsekracji}

„Sakrament ołtarza dokonuje się mocą słów Chrystusowych”, mówi Franciszek w Liście do catego zakonu ${ }^{13}$, czyli za pośrednictwem słów Jezusa, które kapłan powtarza w formule konsekracyjnej. Te „słowa Boże” były wówczas, podobnie jak i dziś bywa, wypisane na tabliczkach lub na pergaminach i kładzione na ołtarzu, by celebrans nie pomylił ani jednej sylaby w ich wymawianiu $^{14}$. Tak więc św. Franciszek do czci dla Jezusa w Eucharystii dołączył ściśle szacunek dla „słów Bożych”: „Upominam wszystkich moich braci i zachęcam w Chrystusie, aby gdziekolwiek znajdą słowa Boże napisane, uszanowali je, jak tylko mogą, i jeśli nie są należycie przechowywane lub leżą bez szacunku w jakimś miejscu rozrzucone, o ile tylko od nich to zależy, niech je zbiorą i złożą, czcząc w tych słowach Pana, który je wypowiedział" 15 .

Z tego ścisłego związku czci św. Franciszka dla sakramentu ołtarza i dla słowa Bożego, który potwierdzają jeszcze inne jego wypowiedzi i świadectwa źródłowe o nim, wynika organiczna łączność liturgii Słowa z liturgią Eucharystii. Szczególną miłość Franciszka do słuchania Ewangelii zaznaczył brat Leon w nocie na brewiarzu Świętego: „Kazał też napisać ten Ewangeliarz, i kiedy z powodu choroby lub innej oczywistej przeszkody nie mógł słuchać Mszy, to wtedy kazał sobie czytać urywek ewangeliczny, wyznaczony na Mszę tego dnia. I tak czynił aż do swojej śmierci. Podawał taką rację: Kiedy nie słucham Mszy, to adoruję ciało Chrystusa w modlitwie oczyma ducha w taki sam spo-

11 Tamże, w. 13.

12 Pisma..., s. 318-320 (Aneks).

13 List skierowany do catego Zakonu, w. 37, [w:] Pisma..., j.w., s. 196.

${ }^{14}$ E. Franceschini, jw., s. 43.

${ }^{15}$ List skierowany do całego Zakonu, w. 35-36, [w:] Pisma..., s. 196. 
sób, w jaki adoruję wtedy, kiedy Go kontempluję w czasie celebrowania Eucharystii. Po wysłuchaniu lub przeczytaniu fragmentu Ewangelii, ze względu na swój głęboki szacunek dla Pana, zawsze całował księgę Ewangelii"16. Podobne świadectwo znajduje się w Speculum perfectionis: „Zawsze, kiedy nie mógł wysłuchać Mszy św., chciał przed posiłkiem wysłuchać Ewangelii, czytanej na Mszy w owym dniu"17. Chodzi tu nie tylko o zbieżność między liturgią Słowa a liturgią Eucharystii, między stołem Słowa i stołem Ciała Pańskiego, ale też o miejsce, jakie Msza św. zajmowała w jego dniu, jako że wtedy, kiedy słucha Ewangelii, wewnętrznie adoruje ciało Chrystusowe i duchowo wtapia się w rytm celebry eucharystycznej każdego dnia ${ }^{18}$.

\section{Kapłan jako szafarz Eucharystii}

Sw. Franciszek wiedział, że celem człowieka jest zjednoczenie z Bogiem i że pośrednikiem do tego celu jest kapłan. Taki jest zbawczy plan Boży ${ }^{19}$. Dlatego w Liście do wiernych napisał: „Bądźmy wszyscy głęboko przekonani, że nikt nie może inaczej się zbawić, jak tylko przez święte słowa i Krew Pana naszego Jezusa Chrystusa, które duchowni głoszą, przekazują i udzielają. I tylko oni mogą to czynić, nikt inny"20. Znana jest tradycja, która znalazła wyraz w sztuce religijnej, np. w obrazie J. Ribery, że Franciszek nie przyjął święceń kapłańskich, pozostając tylko diakonem, gdyż czuł się niegodnym tego sakramentu i lękał się płynących z niego obowiązków. Dlatego Franciszek był zatroskany o świętość kapłanów. Dał temu wyraz w Liście do duchownych ${ }^{21}$ :

Zwróćmy uwagę, wszyscy duchowni, na wielki grzech i nieświadomość niektórych względem najśw. Ciała i Krwi Pana naszego Jezusa Chrystusa oraz względem najśw. imion i słów Jego napisanych, które uświęcają ciało ${ }^{21 a}$. [...] Wiemy, że Jego Ciało nie może być obecne, jeśli nie odbyła się przedtem konsekracja przez słowo. Wszyscy szafarze tych najświętszych tajemnic, zwłaszcza ci, którzy to czynią bez szacunku, zastanowienja się, jak liche są kielichy, korporały i obrusy, które służą do ofiary Ciała i Krwi Jego. I wielu przechowuje Cialo i pozostawia Je w miejscach niewłaściwych, nosi w sposób godny oplakania i przyjmuje niegodnie, i udziela innym nieodpowiedzialnie. Także imiona i słowa Jego napisane bywają deptane stopami [...] Czy to wszystko nie przejmuje nas miłością, skoro sam Pan w swojej łaskawości daje Siebie w nasze ręce i codziennie Go dotykamy i przyjmujemy naszymi ustami? Czyż nie wiemy, że musimy znaleźć się w Jego rękach?[...]

Gdziekolwiek najświętsze Ciało Pana naszego Jezusa Chrystusa byłoby niegodnie umieszczone i zostawione, należy je z takiego miejsca zabrać i zabezpieczyć. Podobnie, gdyby

${ }^{16}$ Il Breviario di San Francesco. Nota di Frate Leone, [w:] Fonti Francescane, t. 2, Assisi 1977, s. $2165-2166$.

${ }^{17}$ Wczesne źródła franciszkańskie, t. 2, Warszawa 1981, s. 258.

${ }^{18}$ R. Falsini, Eucaristia, [w:] Dizionario Francescano, Padova 1983, col. 536-537.

${ }^{19}$ S. Kafel, Kapłan w oczach św. Franciszka, „Homo Dei” 4:1976 s. 270.

${ }^{20}$ Pisma ..., S. 171.

${ }^{21}$ List do duchownych, [w:] Pisma..., s. 185-188.

21a Chodzi tu o slowa konsekracji. Sw. Franciszek nie używal jeszcze terminu „przeistoczenie", ale dawny termin: consecratio - uświęcenie. 
imiona i słowa Pańskie napisane znalazły się gdziekolwiek w miejscach nieodpowiednich, należy je zabrać i złożyć w miejscu stosownym. To wszystko aż do końca obowiązani są wszyscy duchowni ponad wszystko zachowywać. A którzy tego nie uczynią, niech wiedzą, że wobec Pana naszego Jezusa Chrystusa zdadzą rachunek w dniu sądu.

\section{Przygotowanie do Komunii św.}

Pobożność ówczesna była żywiołowa, ale przede wszystkim zewnętrzna. Nabożeństwa, procesje i kazania sławnych kaznodziejów gromadziły tłumy ludzi. Kult relikwii i miejsc świętych zaludniał drogi pielgrzymami spragnionymi odpustów i cudów. Kult Eucharystii również był bardziej zewnętrzny, koncentrował się na widzeniu i adoracji świętych Postaci, stąd to na początku XIII w. ustalił się i rozszerzył obrzęd podniesienia po konsekracji. Komunia „oczna” bywała brana za komunię sakramentalną, a nawet pierwszej przypisywano większe skutki aniżeli drugiej22. Strach przed świętokradztwem powstrzymywał wiernych od Komunii św. Jeżeli św. Ludwik, król francuski, komunikował się 6 razy do roku, a reguła św. Klary ustalała Komunię siedmiorazową, to cóż dopiero mówić o Komunii zwykłych wiernych?23.

Sw. Franciszek nie wspomina o obrzędzie podniesienia, a jeśli używa zwrotu „widzieć ciało Pana”, to chodzi mu o widzenie wiary. Nie dał się więc porwać przez prądy dewocyjne, ale zachował umiar teologiczny. Jego cześć dla Jezusa eucharystycznego jak najbardziej łączyła się ze świętą bojaźnią ${ }^{24}$, ale nie odrywała go od pragnienia komunii sakramentalnej, ani nie przeszkodziła mu w częstym osobistym komunikowaniu, w czym wyprzedził swoją epokę. Równocześnie na wszelkie sposoby szerzył cześć dla Najświętszego Sakramentu i zachęcał do Komunii św., co znalazło odbicie nawet w Liście do rządców narodów: „Usilnie radzę wam, moim panom, abyście odsunęli od siebie wszystkie troski i zabiegi i przyjmowali z uniżeniem najświętsze Ciało i najświętszą Krew Pana naszego Jezusa Chrystusa w jego świętej pamiątce. I tak wielką cześć dla Pana rozszerzajcie wśród ludu wam powierzonego"25.

Ten akcent na Komunię eucharystyczną Franciszek łączył ściśle z dyspozycjami, jakie winien mieć przyjmujący Ciało i Krew Pana. Winien być czysty sercem i ciałem: „I chcę, abyśmy wszyscy zostali przez Niego zbawieni i przyjmowali Go czystym sercem i czystym ciałem. Lecz niewielu jest takich, którzy pragną Go przyjmować i dostąpić przez Niego zbawienia, chociaż jarzmo Jego jest słodkie, a brzemię lekkie"26. Czystość serca potrzebną do Komunii św. otrzymuje się w sakramencie pokuty: „Niech nie omieszkają zwrócić się do ka-

\footnotetext{
${ }^{22}$ R. Falsini, jw., col. 529.

${ }^{23}$ A. Ż y n el, Kult Eucharystii w życiu św. Franciszka, „Homo Dei” 4: 1976 s. 256.

${ }^{24}$ Por. H. Feld e r, Die Lehre des hl. Franziskus von Assisi, Paderborn 1923, s. 57-58.

${ }^{25}$ List do duchownych, w. 6-7, [...] Pisma..., s. 181.

26 2. List do wiernych, w. $14-15$, [w:] tamże, s. 169.
} 
płana, bo tylko kapłani otrzymali władzę związywania i rozwiązywania. I po takim żalu i spowiedzi niech przyjmują Ciało i Krew Pana naszego Jezusa Chrystusa $\mathrm{z}$ wielką pokorą i czcią pamiętając, co Pan mówi: Kto pożywa Ciało moje i pije Krew moja, ma życie wieczne, $(\mathrm{J} 6,55)$ i: To czyńcie na moja pamiatke" $($ Łk 22, 19) 27.

Owczesna częstotliwość przystępowania do sakramentu pokuty i Komunii była wręcz odwrotna do praktyki dzisiejszej, bo spowiedź była częstsza a Komunia rzadsza, np. obydwie reguły Sióstr Klarysek, tzn. reguła św. Klary i reguła Urbana IV, przepisywała spowiedź raz w miesiącu, a Komunię św. siedem razy $w$ roku, na większe uroczystości ${ }^{28}$. $Z$ tego porównania wynika nie tylko ten wniosek, że spowiedź zawsze była warunkiem do Komunii, ale też inny charakter jednego i drugiego sakramentu. Przystępowanie do spowiedzi miało niejako charakter powszedni, a przystępowanie do Eucharystii charakter uroczysty. U św. Franciszka nie mamy wyznaczonej częstotliwości korzystania z obydwu sakramentów, mamy natomiast stale podkreślaną potrzebę przystępowania do nich oraz zasadę ogólną, wyrażającą ich łączność: „Powinniśmy się spowiadać przed kapłanem ze wszystkich grzechów naszych i przyjmować od niego Ciało i Krew Pana"29. Zasada ta nie tylko jest poprawna teologicznie, ale także zdrowa i pewna w życiu ascetycznym, jak również bardzo płodna w działalności duszpasterskiej.

\section{Eucharystia wspólnotowa}

W czasach św. Franciszka nie istniało koncelebrowanie mszy św., a także słabła wspólnotowość uczestnictwa w niej na rzecz celebracji indywidualnej. M. in. już znacznie wcześniej Piotr Venerabilis, opat z Cluny, skarżył się, że msze „prywatne” tak rozbijają wspólnotę, iż na msze „wspólne” przychodzi zaledwie jedna czwarta zakonników ${ }^{30}$. Na tym tle zaskakujące było wskazanie św. Franciszka dla całego zakonu, by wszędzie w klasztorach odprawiano tylko jedną mszę św., w której by uczestniczyli wszyscy zakonnicy, tak kapłani, jak i bracia zakonni ${ }^{31}$ :

Upominam i zachęcam w Panu, aby w miejscach gdzie przebywają bracia, była odprawiana w ciągu dnia tylko jedna Msza św. według przepisów Kościoła świętego. Jeśli zaś jest na miejscu więcej kapłanów, nich jeden zadowoli się z miłości uczestnictwem we Mszy odprawianej przez drugiego kapłana; bo Pan Jezus Chrystus napełnia obecnych i nieobecnych, którzy są tego godni. Chociaż Go widać w wielu miejscach, pozostaje jednak niepodzielny i nie doznaje żadnego uszczerbku, lecz jeden działa wszędzie, jak Mu się podoba, z Panem Bogiem Ojcem i z Duchem Świętym Pocieszycielem na wieki wieków.

${ }^{27}$ Reguta niezatwierdzona, r. 20, [w:] tamże, s. 80-81.

28 Wczesne źródta franciszkańskie..., t. 2 s. $312,419$.

${ }^{29}$ 2. List do wiernych, w. 22, [w:] Pisma..., s. 170.

${ }^{30}$ A. Żynel, jw., s. 260; R. Falsini, jw., col. 527.

${ }^{31}$ List skierowany do catego Zakonu, w. 30-33, [w:] Pisma..., s. 195-196. 
Trzeba tu podziwiać intuicję św. Franciszka, który nie będąc teologiem, już wtedy wyczuwał swym zmysłem religijnym znaczenie Pawłowej teologii Kościoła jako Mistycznego Ciała, powszechnego kapłaństwa i wspólnego charakteru Ofiary eucharystycznej ${ }^{32}$.

\section{DZIEDZICTWO DUCHOWOSCI EUCHARYSTYCZNEJ W RODZINIE FRANCISZKAŃSKIEJ}

Eucharystyczny charyzmat św. Franciszka nie tylko został zachowany przez jego braci mniejszych, ale wzrósł w ciągu stuleci. Z jednej strony Eucharystia stała się tematem refleksji teologicznej, z drugiej zaś przedmiotem pobożności i ośrodkiem życia chrześcijańskiego. Słusznie stwierdzono, że duchowość franciszkańska pobiera pokarm duchowy z pięciu wielkich tajemnic naszej wiary: Boga jedynego w Trójcy, Jezusa Chrystusa, Maryi, Kościoła i Eucharystii ${ }^{33}$. Teologię eucharystyczną opracowywali przede wszystkim: Aleksander z Hales, Wilhelm z Melitona, św. Bonawentura i Jan Duns Szkot. Ich doktryna da się ująć w czterech punktach:

1. Centralna pozycja tajemnicy Eucharystii. Teologowie franciszkańscy, idąc po linii tradycyjnego uwielbienia dla Eucharystii, zgodnie uznawali w tajemnicy obecności Boga-Człowieka i Jego codziennej ofiary żywe centrum karmiące pobożność chrześcijańską i szczytowy punkt calej sakramentalnej ekonomii odkupienia, bo podczas gdy inne sakramenty są jakby strumieniami życia Bożego, to w sakramencie Eucharystii mieszka sama pełnia łaski, Słowo wcielone.

2. Sakrament miłości. W tradycji teologicznej, patrystycznej i scholastycznej, jest głęboko zakorzeniony związek Eucharystii z miłością. Przejęła go teologia franciszkańska. Fakt ustanowienia Eucharystii i jego okoliczności wskazują, że jest ona ostatecznym wyrazem i najwyższym szczytem miłości, która się daje. Dlatego utożsamiono ją z samą miłością i zwano po prostu sakramentem miłości. Było to ujęcie bardzo płodne w określeniu roli Eucharystii w życiu duchowym.

3. Sakrament jedności z Chrystusem. Eucharystia mocą swej asymilacji dokonuje głębokiego zjednoczenia członków Ciała mistycznego z głową Chrystusem, z którego na całe ciało płynie limfa życia Bożego. Alegoria szczepu winnego i gałązek, za pomocą którego Jezus wyraził tę mistyczną rzeczywistość, znajduje w życiu sakramentalnym sposób najbardziej skuteczny i najbardziej odpowiadający naturze ludzkiej. Według doktorów franciszkańskich, Eucharystia udziela łaski szczególnej, by jednoczyć członki z głową w Ciele mi-

32 A. Żynel, jw., s. 260.

${ }^{33} \mathrm{~L}$. L or s che id e r, I fondamenti teologici della spiritualità francescana, [w:] Quaderni di spiritualità francescana, z. 1: Che cosa'è la spiritualità francescana, Assisi 1964, s. 55-82. 
cznym. Tak więc Eucharystia jest prawdziwie wielką drogą sakramentalną do osiągnięcia doświadczenia mistycznego, co podkreśla zwłaszcza św. Bonawentura.

4. Sakrament jedności Ciata mistycznego. Eucharystia nie tylko realizuje indywidualną doskonałość poprzez wzrost miłości i zjednoczenie życia z Jezusem, ale żywi ona też wzajemną jedność członków Ciała mistycznego. Ta prawda, wzięta przez tradycję patrystyczną od św. Pawła (1 Kor 10,17), stała się przedmiotem opracowań przez teologów franciszkańskich, szczególnie wnikliwie traktowanym przez św. Bonawenturę: „Chrystus ukrywa się właśnie pod tymi dwoma postaciami, dlatego że chleb i wino [...] doskonale oznaczają mistyczne Ciało Chrystusa, mianowicie Kościół złożony z przeznaczonych do życia wielu wiernych, jakby z licznych ziaren i winnych jagód. Jak niegdyś Bóstwo ukryło się w łonie Dziewicy, a Syn Boży ukazał się światu w sposób widziaIny pod osłoną ciała ludzkiego, tak samo uwielbione człowieczeństwo, złączone z Bóstwem, ukrywa się pod postacią chleba i wina, aby udzielać się nam śmiertelnym"34.

W czasie, kiedy teologia eucharystyczna przechodziła ze stanu fragmentarycznego do opracowania systematycznego i całościowego, teologowie franciszkańscy znacznie przyczynili się do dania Eucharystii miejsca centralnego w ekonomii sakramentalnej i w ogóle w ekonomii zbawienia. Z wielką żarliwością uczyli, że Eucharystia, która jest sakramentem miłości i jedności członków Ciała mistycznego z głową Chrystusem, stanowi wielką drogę, prowadzącą do osiągnięcia najwyższych stopni poufnej przyjaźni z Bogiem ${ }^{35}$. Nauka teologów franciszkańskich docierała do uczonych w zakonie, natomiast na wszystkich jego członków działała żywa tradycja, skoro ustny przekaz był wówczas głównym sposobem kształcenia i informowania. Tradycja ta łączyła się z postaciami, które obok św. Franciszka z Asyżu znalazły stałe miejsce w duchowości i apostolstwie minorytów. Były to przede wszystkim dwie postacie: św. Antoni Padewski (+ 1231) i św. Klara z Asyżu $(+1253)^{36}$.

Za św. Antonim szła sława cudów za życia i po śmierci. Wśród nich szczegóIną wymowę miał cud, będący znakiem obecności Jezusa w Eucharystii, mianowicie sławny cud z mułem katara Bonillo w Rimini, twierdzy herezji. Bo oto zwierzę, choć głodzone przez dwa dni, nie rzuciło się do jedzenia podanego sobie obroku, ale klęknęło przed Najświętszym Sakramentem, ukazanym mu

34 Tractatus de praeparatione ad Missam, nr 2 i 4, [w:] Św. B o n a w e n t u r a, Pisma ascetyczno-mistyczne, Warszawa 1984, s. 248; S. Si m o n is, De causalitate Eucharistiae in corpus mysticum. Doctrina S. Bonaventurae, „Antonianum” 8, 1933, 407-408.

${ }^{35} \mathrm{~V}$. N a t a l in, Il mistero eucaristico nel pensiero teologico francescano, [w:] Quaderni di spiritualità francescana, z. 3: L'Eucarestia, jw., s. 53-71.

${ }^{36} \mathrm{Z}$ innych późniejszych czcicieli Eucharystii w rodzinie franciszkańskiej wymienia się najczęściej św. Mikołaja Picka i towarzyszy męczenników z Gorcum w Holandii (1572 r.), św. Paschalisa Baylona, którego Leon XIII w r. 1898 ogłosił patronem eucharystycznych kongresów, stowarzyszeń i dzieł, oraz św. Karola z Sezze. 
przez Antoniego ${ }^{37}$. Ten cud wskazuje na apologetyczną wartość działalności św. Antoniego przeciw wciąż szerzonym błędom Berengariusza z Tours, że przemiana chleba i wina w ciało i krew Jezusa jest niemożliwa, a stąd że obecność Chrystusa w Eucharystii nie jest realna. Tak więc popularność św. Antoniego przyczyniła się walnie do umacniania wiary w Eucharystię i budzenia czci dla Niej. Ponadto św. Antoni, pierwszy pisarz teologiczno-kaznodziejski w zakonie minorytów, oddziaływał swoimi kazaniami pisanymi. W wieku XIII i XIV były one podręcznikiem dla kaznodziejów franciszkańskich, o czym świadczy duża ilość rękopisów tych kazań pozostałych z owego czasu. Św. Antoni daje w nich naukę o Eucharystii jasną, dokładną, względnie kompletną. Główne jej punkty to: rzeczywista obecność Jezusa w Eucharystii, sposób w jaki się ona dokonuje, skutki Eucharystii, obowiązek jej przyjmowania, dyspozycje konieczne do godnego komunikowania, cel Eucharystiii ${ }^{38}$.

Wśród postaci kobiecych, które w średniowieczu dały świadectwo Eucharystii, na pierwsze miejsce wysuwa się św. Klara z Asyżu. Jednocześnie jest ona najbardziej autentyczną tłumaczką duchowości św. Franciszka, jego najwierniejszym odbiciem w świecie niewieścim. Sladem św. Franciszka, który był apostołem i żarliwym odnowicielem kultu eucharystycznego, Klara skierowała swe życie i życie Ubogich Pań ku Eucharystii. Ten fakt, że reguła przepisywała siostrom klaryskom Komunię św. tylko siedem razy w roku, nie pomniejsza ich gorliwości eucharystycznej. Ten przepis trzeba oceniać w kontekście czasu. Był on w zgodzie z interpretacją ówczesnych teologów, którzy w swych opracowaniach nie dawali mocnej podstawy do częstej Komunii św. Natomiast w porównaniu do ogólnego wówczas zaniedbania w przystępowaniu do Komunii ustanowienie siedmiokrotnego komunikowania się było przełamaniem lęku przed Eucharystią, panującego w ówczesnym Kościele.

Pierwszy biograf św. Klary, brat Tomasz z Celano, który osobiście znał Klarę i klasztor Św. Damiana pod Asyżem, zapisał: „Jak wielką była miłość i pobożność św. Klary względem sakramentu ołtarza, wykazują fakty. W ciężkiej chorobie, która ją przykuła do posłania, podnosiła się i podpierała z tyłu, i tak siedząc, przędła jak najcieńsze tkaniny. $Z$ tych tkanin zrobiła więcej niż pięćdziesiąt korporałów. Włożywszy je do burs z jedwabiu albo z purpury, przeznaczała je do różnych kościołów w dolinie i na górach Asyżu. Gdy miała przyjąć Ciało Pańskie, najpierw wylewała gorące łzy, a potem przystępowała doń z drżeniem, bo nie mniej lękała się Boga ukrytego w sakramencie, aniżeli Boga władającego niebem i ziemią" 39 .

Między relacjami świadków procesu są takie, które wskazują na szczególne, mistyczne zjednoczenie Klary z Chrystusem eucharystycznym, np. zezna-

${ }^{37}$ Por. C. Niezgoda, Sw. Antoni Padewski. Życie i nauczanie, Warszawa 1984, s. 54.

38 Tamże, s. 133, 307-311.

${ }^{39}$ To masz z Cela no, Legenda ośw. Klarze z Asyżu, [w:] Wczesne źródta franciszkańskie, t. 2 , jw., s. 392 . 
nie s. Franciszki z Coldimezzo: „Jednego razu, gdy Siostry myślały, że błogosławiona Matka jest już bliska śmierci, a kapłan udzielił jej świętej Komunii Ciała Pana naszego Jezusa Chrystusa, ona, świadek, widziała nad głową św. Klary bardzo wielki blask. I zdało się jej, że Ciało Pana było dziecięciem małym i bardzo pięknym. A potem, po przyjęciu Go z wielką pobożnością i łzami, św. Klara powiedziała te słowa: Dzisiaj Bóg obdarzył mię tak wielkim dobrodziejstwem, że niebo i ziemia nie potrafią Mu zadośćuczynić"40.

Żeby wzmóc swą cześć i miłość dla Eucharystii, kazała w kaplicy poświęconej Najśw. Dziewicy urządzić miejsce przechowywania Najświętszego Sakramentu. Była to nowość, bo w owych czasach nie zawsze postacie eucharystyczne przeznaczone dla chorych były strzeżone w miejscu odpowiednim. Będąc chora, obrała sobie celkę przyległą do kaplicy i tak korzystała z bliskości Pana. Całe godziny w ciągu dnia i nocy poświęcała na rozważanie, modlitwę ustną i kontemplację, pociągając swoim przykładem inne siostry. Dzięki niej tabernakulum stało się u Sw. Damiana centrum pobożności całej wspólnoty klasztornej. Z tej racji biografowie nazwali ją „,seraficką westalką Najświętszego Sakramentu” I „twórczynią wieczystej adoracji eucharystycznej”41.

Najbardziej jednak św. Klara przyczyniła się do kultu Eucharystii swoją modlitewną interwencją w czasie napadu soldateski saraceńskiej Fryderyka II na klasztor Św. Damiana oraz oblężenia Asyżu przez wojska Witalisa z Aversa. Wspomniana wyżej s. Franciszka, towarzysząca wówczas Klarze, relacjonuje w procesie kanonizacyjnym: „Gdy Saraceni weszli do chiostro klasztoru, pani Klara kazała się zaprowadzić do drzwi refektarza i kazała nieść przed sobą kasetę, w której był święty sakrament Ciała Pana naszego Jezusa Chrystusa. I rzuciwszy się na ziemię do modlitwy, ze łzami modliła się, mówiąc między innymi te słowa: - Panie, strzeż te swoje służebnice, ponieważ ja nie mogę ich ustrzec. Wtedy świadek usłyszała głos o cudownej słodyczy, który mówił:- Ja zawsze będę cię bronił. Wtedy modliła się także o miasto, mówiąc: - Panie, niech $\mathrm{Ci}$ się spodoba obronić też to miasto. I ten sam głos zabrzmiał i rzekł: Miasto ucierpi wiele niebezpieczeństw, ale będzie ocalone. Wówczas pani Klara zwróciła się do Sióstr i powiedziała do nich: - Nie trwóżcie się, ponieważ ja jestem dla was rękojmią, że ani obecnie nie poniesiecie żadnego zła, ani też nie stanie się to w innym czasie, dopóki będziecie posłuszne przykazaniom Bożym. Wtedy Saraceni odeszli w taki sposób, że nie uczynili żadnej szkody ani krzywdy" 42 .

Po odejściu Saracenów z klasztoru Św. Damiana i po odstąpieniu wojsk cesarskich od oblężenia Asyżu, mieszkańcy przypisali swe ocalenie modlitwom św. Klary i jej sióstr zakonnych, dlatego obok tytułu „serafickiej westalki Najświętszego Sakramentu” dano jej przydomek „obrończyni ojczyzny” — castel-

40 Proces kanonizacyiny św. Klary z Asyżu, tamże, s. 360-361.

${ }^{41}$ L. B ra cal on i, S. Chiara d'Assisi, Milano 1928, s. 190, 195.

${ }^{42}$ Proces kanonizacyjny..., s. 359. 
lana della patria. Wpływ Klary na rozwój kultu eucharystycznego, tak w XIII wieku, jak i w następnych stuleciach, był znaczny. Artyści przedstawiali ją jako czcicielkę Eucharystii z cyborium w ręce, a Rubens nie zawahal się umieścić ją wśród teologów w dyspucie o tajemnicy Najświętszego Sakramentu ${ }^{43}$.

\section{DZIEDZICTWO EUCHARYSTYCZNE FRANCISZKANÓW W KRAKOWIE}

Wprawdzie wśród pierwszych towarzyszy św. Franciszka z Asyżu przeważali bracia bez święceń, ale byli także kapłani, np. brat Sylwester i brat Leon. Kapłanem, który przeszedł do braci mniejszych od kanoników regularnych był św. Antoni Padewski. Pod koniec r. 1223 św. Franciszek, zapewne zmuszony rozwojem zakonu i przekonany do mądrości i świętości Antoniego, powierzył mu nauczanie teologii: „Uważam to za dobre, że wykładasz świętą teologię braciom, byle byś tylko podczas tego studium nie gasił ducha modlitwy i pobożności, jak mówi reguła" 44 . Od tej chwili zakon stawał się bardzo szybko coraz bardziej klerycki, a równocześnie umacniała się w nim duchowość eucharystyczna i postępowała reforma liturgii. Chwilą przełomową była kapituła zakonu w Rzymie (15 maja 1239 r.), która po raz pierwszy wybrała na ministra generalnego kapłana - brata Alberta z Pizy. Największą radością kapituły było to, że Albert, jako przełożony, odprawił braciom mszę św. ${ }^{45}$ Od tego czasu doszła do głosu nowa generacja franciszkanów, wykształcona w środowiskach uniwersyteckich i ona nadawała ton życiu zakonu. Kolejnymi generałami byli profesorowie teologii: Haymo z Faversham (1240-1244), którego głównym dziełem była reforma liturgii, bł. Jan z Parmy (1247-1257) i św. Bonawentura (1257-1274). Bracia tej generacji wytyczyli główne kierunki działalności i przeprowadzili stabilizację życia wewnątrz zakonu, czego w pierwszym rzędzie dokonał św. Bonawentura za pomocą Konstytucji, zwanych narbońskimi, jako że zostały przyjęte przez kapitułę w Narbonie w 1260 roku $^{46}$.

Już 4 maja 1227 roku papież Grzegorz IX dał braciom mniejszym przywilej przechowywania Najświętszego Sakramentu i odprawienia uroczystych mszy św. oraz innych nabożeństw we wszystkich ich kościołach i miejscach pobytu ${ }^{47}$. Później generał Haymo w sposób zasadniczy wzmocnił pozycję kapłanów

${ }^{43}$ I. Co n ce t $\mathrm{t}$, Testimonianze eucaristiche di alcuni santi francescani, [w:] Quaderni di spiritualità francescana, z. 3, jw., s. 97. - Por.: Antologia mistyków franciszkańskich, t. 2, Warszawa 1986, s. 149-152 (św. Ludwik Anjou, biskup Tuluzy), 223 (bl. Aniela z Foligno), 89—95 (św. Malgorzata z Kątony, 79-83 (Roger Bacon).

${ }^{44}$ List do św. Antoniego, [w:] Pisma..., s. 217.

${ }^{45} \mathrm{R}$. Hu be r, A documented history of the Franciscan Order, Milwaukee-Washington 1944, s. $113-114$.

${ }^{46}$ Tamże, s. $153-166$.

47 Bullarium Franciscanum, t. 1, s. 27. 
w zakonie i zmienil jego charakter z laickiego na klerycki, kiedy na kapitule w r. 1240 przeprowadził uchwałę, iż przełożonymi mogą być tylko bracia mający święcenia kapłańskie ${ }^{48}$. Rozwój ten przypieczętował papież Innocenty IV, przyznając w roku 1250 i 1252 kościołom franciszkańskim prawa kościołów kolegiackich ${ }^{49}$. Na tej podstawie klasztory franciszkańskie kształtowały się jako wspólnoty konwentualne, mające prawo duszpasterzowania. Stabilizacja życia klasztornego pociągnęła za sobą pewną stabilność dochodów. Dobrodzieje składali ofiary „na żywność i wydatki”, oraz na budowę kościołów. Popularne stały się fundacje mszalne i odprawianie mszy św. za zmarłych członków rodziny ofiarodawcy ${ }^{50}$. Miało to wpływ na kształtowanie się kultu eucharystycznego we wspólnocie zakonnej, bo życie członków klasztoru skupiało się wokół mszy konwenckiej, jak tego życzył sobie św. Franciszek, a równocześnie pomnożyła się celebracja mszalna o charakterze duszpasterskim na rzecz wiernych i z ich udziałem.

Na tym tle trzeba śledzić początki franciszkanów w Krakowie. Przybyli w 1237 roku jako wspólnota skupiająca się wokół Najświętszego Sakramentu, na podstawie papieskiego przywileju z roku 1227. Prawie od samego początku kształtowali się jako wspólnota klerycka, przyjmująca reformę liturgiczną Haymona z Faversham, który osobiście przewodniczył kapitule prowincjalnej w Pradze w roku $1242^{51}$. Wreszcie na mocy przywilejów kolegiackich klasztor krakowski ukonstytuował się jako dom konwentualny, co zostało usankcjonowane przez Konstytucje narbońskie z roku 1260, które dzieliły klasztory na domy konwentualne $\mathrm{z}$ uprawnieniami duszpasterskimi i na placówki pustelnicze bez takich uprawnień. W Krakowie i w innych klasztorach polskich niepodzielnie panował ustrój konwentualny. Tak więc bracia mniejsi w Krakowie i w całej Polsce wykonywali czynności duszpasterskie. We własnych kościołach mogli publicznie odprawiać msze św., przechowywać Najświętszy Sakrament, odmawiać święte Oficjum na sposób chórowy, używać dzwonków oraz odprawiać pogrzeby chrześcijańskie ${ }^{52}$.

Warto zwrócić uwagę na to, że klasztor krakowski, podobnie jak cała prowincja czesko-polska, powstała w krótkim czasie po kanonizacji św. Franciszka (16 VII 1228), za generalatu brata Eliasza, a z inicjatywy brata Jana z Pian del Carpini, który osobiście znał św. Franciszka. Były więc warunki potrzebne do tego, aby od początku zakorzeniło się tu dziedzictwo duchowe św. Franciszka, na co wskazuje tytuł nadany kościołowi i klasztorowi: Sw. Franciszek z Asyżu. Od tego tytułu poszła na terenie Krakowa i prowincji polskiej popular-

${ }^{48}$ R. Huber, jw., s. 123.

49 Bullarium Franciscanum, t. 1, s. 538 n., 622.

50 A. Zwi e r ca n, Nowe spojrzenie na poczq̨tki franciszkanów w Polsce, „Nasza Przeszłość” 6: 1985 s. $31-32$ s. 27.

51 A. Zwiercan, Franciszkanie w Krakowie, [w:] W nurcie franciszkańskim, Kraków 1987,

52 K. Ka nt a k, Franciszkanie Polscy, t. 1, Kraków 1937, s. 213, 378. 
na do dzisiaj nazwa: franciszkanie. W tej duchowości szczególne miejsce zajmował Najświętszy Sakrament. Nie ulega wątpliwości, że duchowość pierwszych pokoleń franciszkanów w Krakowie była chrystocentryczna o profilu pasyjnym i pokutnym. Tak inspirował ich św. Franciszek, który za naczelną zasadę życia minorytów przyjął naśladowanie Jezusa Chrystusa. Dla św. Franciszka Jezus był przede wszystkim Chrystusem ukrzyżowanym; stąd jego kult Męki Pańskiej i udział w krzyżu przez pokutę. Dla niego brat mniejszy to ten, kto sam pokutuje i równocześnie pokutę głosi. Stąd kaznodziejstwo franciszkańskie średniowieczne było przepowiadaniem pokutnym, a główną posługą duszpasterską było szafarstwo sakramentu pokuty, z którego klasztor krakowski słynie po dziś dzień. Dowód na franciszkańską ascezę, jako naśladowanie Jezusa cierpiącego, mamy zwłaszcza w przykładzie polskich błogosławionych klarysek: Salomei, Kingi i Jolenty, kierowanych w życiu duchowym przez franciszkanów ${ }^{53}$.

O pierwszorzędnym znaczeniu kultu Męki Pańskiej u minorytów polskich w XIII I XIV w. świadczą patronowie kościołów klasztornych. Obok Matki Bożej i św. Franciszka najczęstszym był tytuł Krzyża Swiętego: w Radomsku, Radziejowie, Lwowie, Lidzie, u klarysek w Głogowie. „Niezawodnie ze szczególniejszą uroczystością obchodzono oba święta Krzyża - Znalezienie (3 maja) i Podwyższenie (14 września), zapewne z odpustami, z procesją, o ile miano św. Krzyża relikwie [...] Kult Krzyża św. zresztą stanowi część cyklu całej Męki Pańskiej. I tutaj warto przypomnieć o wyobrażeniach jej, jakie jeszcze dzisiaj można oglądać w kościele krakowskim św. Franciszka" ${ }^{54}$.

Z duchowością chrystyczno-pasyjną łączył się kult Matki Bożej Bolesnej, którego ukoronowaniem w XV w. był obraz Smętnej Dobrodziejki. W ikonografii XIV i XV wieku Matka Boża Bolesna występuje razem z Chrystusem, bądź w scenie ukrzyżowania, bądź jako część tryptyku, którego główną postacią jest Ecce Homo lub Chrystus ubiczowany, albo obok Chrystusa „w studni”, czyli w grobie. W ciągu XIV i XV stulecia wyodrębniono już postać Matki Bolesnej, przy równoczesnym ustaleniu jej siedmiu boleści.

U franciszkanów krakowskich w narożu wschodniego i południowego ramienia krużganków stał zamykany ołtarz Miłosierdzia, z figurą Pana Jezusa i Matki Bożej. Figura Pana Jezusa była sławna i ściągała pobożnych. Bardzo możliwe, że był to Pan Jezus „w studni”, albo Pan Jezus pokazujący Maryi ranę boku, co byłoby wyrazem wielkiego kultu ran Chrystusowych, szerzonego przez minorytów, a do czego inspiracją były stygmaty św. Franciszka. Ołtarz ten z powodu zajęcia krużganków przez Austriaków został przeniesiony do kościoła, i tu spłonął w czasie pożaru w roku 1850.

Dowodem na łączność kultu Pana Jezusa cierpiącego i Matki Bożej Boles-

${ }^{53}$ Por. Hagiografia polska, t. 1, Poznań 1971, s. 627 (Jolenta), 764 -765 (Kinga); t. 2, Poznań 1972, s. $304-306$ (Salomea).

${ }^{54}$ K. Kantak, jw., t. 1 s. 217. 
nej są odpusty nadawane przez biskupów krakowskich i innych „ołtarzom Miłosierdzia i Najświętszej Maryi Panny”, z roku 1445. Natomiast dowodem powiązania kultu św. Franciszka stygmatyka z kultem Jezusa cierpiącego są freski średniowieczne na krużganku zachodnim: fresk Jezusa Chrystusa w tłoczni mistycznej i obok fresk stygmatyzacji św. Franciszka. Na fresku tloczni mistycznej, obok postaci cierpiącego Chrystusa, są dwie sceny uzupełniające: maryjna i eucharystyczna. Otóż Chrystus tłoczący prasę jest zwrócony lekkim profilem na prawo tak, że spotyka się z widokiem Maryi, stojącej z rękami złożonymi na prawej krawędzi obrazu. U dołu natomiast są trzy obrazki, z których środkowy przedstawia kapłana przy ołtarzu w trakcie Podniesienia. Do podniesionego kielicha rynienką spływa sok winogron, wyciśniętych w tłoczni, wraz z krwią Chrystusa. Celebransowi usługują dwaj ministranci. Od lewej ręki Jezusa spływa banderola z napisem gotycką minuskułą: „Torcular calcavi solus” $($ Iz 63, 5) 55 . Kojarzy się on zapewne z tym, co pisal św. Bonawentura w Traktacie o przygotowaniu do Mszy św.: „Wino oznacza Krew wyciśniętą przez depczących Żydów z winnego grona, to znaczy z ciała Chrystusowego, w prasie Krzyża" 56 . To skojarzenie ofiary mszy św. z krwawą ofiarą Jezusa wskazuje, obok znaczenia teologicznègo, na historyczną łączność kultu pasyjnego w klasztorze krakowskim z kultem eucharystycznym, zwłaszcza że fresk został namalowany w XV wieku na krużgankach, które służyły kultowi Eucharystii. Ks. Karol Kantak pisze ${ }^{57}$ :

Kult Bożego Ciała przyjął się w Polsce w w. XIV, wówczas to w Krakowie na Kazimierzu stanąl kościól pod takim wezwaniem. Kazimierz ówczesny jednak nie liczył się do miasta. Dlatego Minoryci wybudowali obszerną kaplicę przy swoim kościele, niemal go podwajając, i uczynili ośrodkiem czci tej tajemnicy w obrębie murów miejskich. Co czwartek odbywała się solemna Msza św., niezawodnie z wystawieniem Najśw. Sakramentu, a przed nią procesja teoforyczna po krużgankach kościoła. Uczestnicy dostępowali odpustów. Może wówczas też w oktawę Bożego Ciała z franciszkańskiego kościoła wychodziła wielka procesja po rynku. Kaplicę poświęcil, procesję zaprowadzil, odpusty nadał Zbigniew Oleśnicki przed rokiem 1438. W dyplomie konsekracji kaplicy z wielkimi pochwałami mówi o czci Bożego Ciała, a skoro na synodzie łęczyckim 12 maja 1441, zgromadzeni biskupi udzielili odpustu kościołowi Bożego Ciała i św. Franciszka w Krakowie, to poszło to chyba z jego inicjatywy, a napewno za jego poparciem. Jak intensywna była ta cześć w krakowskim kościele najlepiej zaświadcza mniemanie, jakoby pierwotnie miał wezwanie Bożego Ciała, później dopiero zmienione na św. Franciszka, jak mówi o tym już Długosz.

Obraz wyżej zarysowany stanie się jaśniejszy przez wyszczególnienie dwu aspektów zagadnienia: życia eucharystycznego w łonie wspólnoty klasztornej i apostolstwa eucharystycznego w stosunku do wiernych.

${ }^{55} \mathrm{~K}$. R os e n baige r, Dzieje kościoła Franciszkanów w Krakowie w wiekach średnich, Kraków 1933, s. 142-159, 181-182.

$56 \mathrm{Sw}$. B on a we n t u r a, Pisma ascetyczno-mistyczne, Warszawa 1984, s. 248.

${ }^{57} \mathrm{~K}$. Kantak, jw., t. 1 s. $217-218$. 


\section{Eucharystia w życiu wspólnoty klasztornej}

Najważniejszym i decydującym faktem było to, że nie w żadnej osobnej lub bocznej kaplicy, ale zawsze w prezbiterium przechowywano Najświętszy Sakrament. Tu odbywała się cała służba Boża: msza św. konwentualna, Boskie Oficjum, obrzędy zakonne... Co więcej, prezbiterium było nie tylko miejscem dla żywych, ale i dla zmarłych braci klasztoru, chowanych w krypcie pod ołtarzem. Klasztor żył duchowością św. Franciszka, czyli duchowością pasyjną, w której główną postacią był cierpiący Chrystus, a postacią towarzyszącą Matka Boleściwa. Duchowość ta służyła ascezie pokutnej, przejawiającej się w ubóstwie i prostocie bycia, czemu sprzyjał nie tylko pierwotny ustrój zakonu minorytów, ale również warunki społeczno-gospodarcze kraju, niszczonego przez najazdy tatarskie, zwłaszcza w roku 1241, kiedy zginął gwardian Henryk i jego współbracia, a także przez ciągłe walki książąt piastowskich o senioralne księstwo krakowskie. Z duchowością pasyjną łączyła się duchowość eucharystyczna wspólnoty klasztornej. Siłą rzeczy duchowość tę pielęgnowali bracia kapłani jako szafarze Eucharystii, potem bracia klerycy jako ci, którzy przygotowywali się do kapłaństwa, wreszcie bracia zakonni jako uczestnicy mszy św. konwentualnej i nabożeństw adoracyjnych i procesyjnych.

Na łączność duchowości eucharystycznej z duchowością pasyjną wskazuje wspomniany wyżej fresk Chrystusa w tłoczni mistycznej. Chrystus tłoczący winogrona to Chrystus w krwawej ofierze krzyżowej. Poniżej tłoczni jest obrazek Podniesienia kielicha, do którego spływa Krew Chrystusa, a po bokach sceny pasyjne biczowania i cierpieniem ukoronowania Pana Jezusa. Łatwo tu zauważyć dwa aspekty mszy św.: pasyjny i adoracyjny, czyli że msza św. jest tożsama z krwawą ofiarą Chrystusa i jest przedmiotem czci w Jego Krwi, ukazanej w podniesieniu kielicha. Ofiarna krew Jezusa w tłoczni łączy się z jego krwią w kielichu mszalnym. Tak więc duchowość eucharystyczna tu przedstawiona, zgodnie z ujęciem w pismach św. Franciszka i z ówczesną teologią franciszkańską, nie występuje samodzielnie, lecz jest wtopiona w duchowość pasyjną, która z kolei wymaga szczególnej świętości u tych, którzy Eucharystię sprawują: „Posłuchajcie moi bracia: jeśli Najświętsza Dziewica odbiera, i słusznie, taką cześć, ponieważ nosiła Go w najświętszym łonie; jeśli św. Jan Chrzciciel zadrżał i nie śmiał dotknąć świętej głowy Boga; jeśli szanujemy grób, w którym przez pewien czas spoczywało ciało Chrystusa, to jakżeż święty, sprawiedliwy, godny powinien być ten, który Go rękami dotyka, sercem i ustami przyjmuje i innym do spożywania podaje?" 58

Klasztor krakowski jako kustodialny był od początku domem studiów teologicznych, o co zadbała przede wszystkim bł. Salomea Piastówna ${ }^{59}$. O forma-

${ }^{58}$ List skierowany do catego Zakonu, w. 21-22, [w:] Pisma..., s. 194.

59 Por. M. Ka ni o r, Btogostawiona Salomea, Warszawa 1985, s. 40; A. Ka rw a c ki, Bt. Salomea za życia i po śmierci, Kraków 1911, s. 99. 
cji teologicznej, jako warunku do kapłaństwa, świadczy choćby wymaganie kapituły prowincjalnej z roku 1412, by do święceń dopuszczał jedynie kustosz i by kandydaci mieli odpowiednią wiedzę. W przeciwnym razie popadali w suspenzę od czynności kapłańskich ${ }^{60}$. Formacja kapłańska była oczywiście formacją eucharystyczną.

\section{Kult w działalności duszpasterskiej}

Dnia 25 lipca 1238 r. Jan z Pian del Carpini, prowincjał Saksonii, utworzył prowincję czesko-polską, z podziałem na kustodie. Wśród klasztorów kustodialnych polskich klasztor krakowski wysunął się na pierwsze miejsce. Niejednokrotnie rezydował w nim prowincjał z Pragi, zwłaszcza po wybuchu rozruchów husyckich w Czechach ${ }^{61}$.

Duszpasterstwo klasztoru krakowskiego bazowało na trzech głównych czynnościach: kaznodziejstwie, spowiednictwie i sprawowaniu Eucharystii. Kustosze krakowscy, dysponujący zasobną biblioteką i mający stałe kontakty z ośrodkami zakonnymi w innych krajach, zwłaszcza w Italii, znali wzory życia franciszkańskiego: św. Franciszka, św. Klarę, św. Antoniego, św. Bonawenturę, św. Ludwika biskupa, przynajmniej ich życiorysy i niektóre pisma, a wśród nich List św. Franciszka do kustoszów o Eucharystii. Znajomość tego listu była tym bardziej realna, że św. Franciszek polecił go rozpowszechniać: „Do którychkolwiek braci moich kustoszów dojdzie to pismo, przepiszą i będą mieć u siebie, i przepiszą dla braci, którzy mają obowiązek głoszenia kazań i opiekę nad braćmi; i jeśli wszystko, co zawiera się w tym liście, będą głosić aż do końca, niech wiedzą, że mają błogosławieństwo Pana Boga i moje. I niech tak będzie na mocy prawdziwego i świętego posłuszeństwa. Amen" (w. 9-10). List ten zawierał program eucharystyczny. Chodziło o wpływ braci na duchownych, by czcili Ciało i Krew Pańską, słowa Boże konsekrujące i wszystko, co służy Eucharystii: „Kielichy, korporały, ozdoby ołtarza i wszystko, co służy do Ofiary, niech będą kosztowne" (w. 3); o godności przechowywania Najświętszego Sakramentu, strzeżenia, noszenia, udzielania innym (w. 4); o kazania pokutne jako przygotowanie do Eucharystii: „I w każdym kazaniu, które głosicie, nakłaniajcie lud do pokuty i przypominajcie, że nikt nie może się zbawić, jeśli nie przyjmuje najśw. Ciała i Krwi Pańskiej” (w. 6); o uczenie ludu czci dla Najświętszego Sakramentu: „A gdy kapłan je konsekruje na ołtarzu i na inne miejsce przenosi, niech wszyscy ludzie na klęczkach oddają chwałę, uwielbienie i cześć Panu Bogu żywemu i prawdziwemu" (w. 7) ${ }^{62}$.

Kościół franciszkański w Krakowie bardzo wcześnie stał się kościołem

${ }^{60}$ K. Kantak, jw., t. 1 s. 391.

${ }^{61} \mathrm{~K}$. Kantak, jw., t. 1 s. 169.

${ }^{62}$ List do kustoszów, [w:] Pisma..., s. 206-207. 
duszpasterskim, skoro został poświęcony jeszcze przed rokiem 1249. Praca duszpasterska była widocznie bardzo potrzebna, skoro bracia spotkali się z życzliwością biskupów i kapituły. Dopiero w r. 1335 natrafili na chwilową opozycję ze strony niektórych proboszczów. Wówczas mendykanci skorzystali z pobytu w Krakowie abpa gnieźnieńskiego Janisława, udali się do niego ze skargą. Dnia 15 marca 1335 r. uzyskali jego orzeczenie przeciw rządcom kościołów NM Panny i Wszystkich Świętych w Krakowie, św. Piotra w Sandomierzu, w Zawichoście, Sączu i Lelowie, że ważne są spowiedzi wiernych w kościołach dominikanów i franciszkanów, że nie potrzeba ich powtarzać w świątyniach parafialnych i że nie wolno wiernym odmawiać Komunii św. po spowiedzi tam odprawionej. Zapewne dzięki temu orzeczeniu nie było później zatargów w tej mierze ${ }^{63}$.

\section{ZMIANA PROFILU W DUCHOWOŚCI I DUSZPASTERSTWIE FRANCISZKANOW KRAKOWSKICH}

Jest rzeczą stale doświadczaną, że również w działalności kościelnej odgrywają rolę bodźce materialne. Św. Franciszek bardzo mocno postawił sprawę ubóstwa ewangelicznego w zakonie i zdobywania środków na utrzymanie pracą. Taki sposób życia zmuszał po prostu franciszkanów do pracy na rzecz wiernych, by w zamian za świadczone posługi duchowne otrzymać środki materialne. Była to więc zależność zakonników od społeczeństwa, a przez to otwarcie się ich na potrzeby społeczne. Tak było też w Krakowie.

Jednakże ta sytuacja ulegała zmianie, mianowicie dokonywało się przechodzenie klasztorów na bardziej stałe i niezależne dochody, co było możliwe w miarę wzrostu zamożności społeczeństwa. Właśnie taki wzrost zamożności społecznej dokonywał się w Krakowie, stolicy rozległego państwa, zjednoczonego przez Władysława Łokietka, umocnionego i zagospodarowanego przez Kazimierza Wielkiego, rozszerzonego przez królowę Jadwigę i Władysława Jagiełłę. Posiadanie terenu pod zabudowę, uzyskanego niegdyś przez bł. Kingę od kapituły krakowskiej i darowanego klasztorowi ${ }^{64}$, a następnie zamożność mieszczan sprawiła, że franciszkanie powiększyli znacznie swą przestrzeń przez rozbudowę kościoła, budowę krużganków i kaplic oraz powiększenie klasztoru. Nabywali też ziemię i legaty, co pozwoliło im na częściową samodzielność gospodarczą.

Temu rozmachowi budowlanemu towarzyszyła wizja duszpasterska, w tym eucharystyczna: gromadzić wielu ludzi na okazałych nabożeństwach, co zapewne wydawało się koniecznością jako przeciwdziałanie czeskiemu husycyzmo-

${ }^{63}$ K. Kantak, jw., t. 1 s. 213-214, 378 (Regesta). s. 81 .

${ }^{64}$ A. Z wi r r c a n, Pierwotny kościót franciszkański w Krakowie, „Nasza Przeszłość” 60: 1983 
wi, który docieral też do Krakowa ${ }^{65}$. Na to wskazuje konsekracja przez Zbigniewa Oleśnickiego nowo zbudowanej świątyni pod tytułem Bożego Ciała i zorganizowanie w niej uroczystych nabożeństw i procesji teoforycznych. Zapewne skojarzyły się tu dwie rzeczy: pewne obniżenie się duchowości zakonnej wewnętrznej i wzrost uroczystości zewnętrznych.

Równocześnie całym zakonem franciszkańskim wstrząsnęły wzajemne tarcia między familią konwentualną a braćmi obserwantami, co w rezultacie doprowadziło do podziału zakonu minorytów w roku 1517. Polskie kustodie nie uległy tym wstrząsom, a tylko po powstaniu w Krakowie w roku 1453 obserwantów, zwanych w Polsce bernardynami, co sprawił św. Jan Kapistran w czasie swego pobytu w Krakowie, niektórzy pojedyńczy franciszkanie przeszli do nowej wspólnoty, m. in. bł. Jan z Dukli66. Obserwanci stali się popularni w Krakowie, zyskując tlumne powołania, zwłaszcza ze środowisk uniwersyteckich. Bernardyni byli od razu bardzo prężni, nie tylko w życiu zakonnym, ale i w działalności duszpasterskiej, później zaś w działalności misyjnej na wschodnich terenach kraju - Rusi i Litwie ${ }^{67}$.

Franciszkanie zeszli na dalszy plan. Wyraźnie przeżywali kryzys wzrostu. Tak osłabioną wspólnotą z kolei wstrząśnie protestantyzm, pod którego wpływem mocno zachwieje się kult eucharystyczny. Franciszkanie polscy osłabli, ale nie upadli. Późniejsze ich dzieje wykazały, że są zdolni do odnowy i w zakresie życia wewnątrzzakonnego, i w zakresie duszpastersko-apostolsko-misyjnym. Kult eucharystyczny stracił swą nadmierną spektakularność, natomiast utrzymał się kult Matki Bożej Bolesnej oraz wkroczył z nową siłą kult pasyjny z chwilą, kiedy w roku 1595 ks. Marcin Szyszkowski, kanonik krakowski, późniejszy biskup płocki, założył przy kościele Franciszkanów, w dawnej kaplicy Bożego Ciała, Bractwo Męki Pańskiej68. Od tego czasu do dzisiaj kaplica ta stała się ośrodkiem pasyjnym, nawiązując w ten sposób do najstarszej tradycji franciszkanów krakowskich ${ }^{69}$.

Dziś, zwłaszcza po soborze Watykańskim II, u franciszkanów krakowskich pierwszym jest kult eucharystyczny. Tak życie klasztorno-seminaryjne, jak i akcja duszpasterska koncentruje się wokól ołtarza Najświętszego Sakramentu. Drugim jest kult Matki Bożej Bolesnej w kaplicy-sanktuarium Smętnej Dobrodziejki, a także Maryi Niepokalanej, wzmożony przez św. Maksymiliana Kolbego. Trzecim jest kult pasyjny w kaplicy Męki Pańskiej, gdzie zwykł był

${ }^{65}$ Por. J. U m ińs k i, Historia Kościoła, t. 1, Opole 1959, s. 573-574.

${ }^{66}$ K. Ka nt a k, Bernardyni Polscy, t. 1, Lwów 1933, s. 1-15.

${ }^{67}$ Tamże, s. $163-202 ;-$ H. W y cza w ski, Krótka historia zakonu braci mniejszych. Zakon w Polsce, [w:] Klasztory bernardyńskie w Polsce w jej granicach historycznych, Kalwaria Zebrzydowska 1985 , s. $619-631$. s. 94.

68 A. Zwi e rca n, Bractwo Męki Pańskiej w Krakowie, „Prawo Kanoniczne” $26: 1983$ nr 1-2

${ }^{69}$ Por. C. Ni z goda, Kaplica Męki Pańskiej w kościele św. Franciszka z Asyżu w Krakowie, [w:] W nurcie franciszkańskim, Kraków 1987, s. 89-90. 
odprawiać swą Drogę Krzyżową Jan Paweł II, gdy był pasterzem Kościoła krakowskiego. Inne kulty spełniają rolę drugorzędną i niejako służebną: św. Franciszka z Asyżu, św. Antoniego Padewskiego, św. Maksymiliana Kolbego, bł. Salomei.

Kiedyś, na kilka lat przed przybyciem braci mniejszych do Krakowa, św. Antoni Padewski podał schemat ich duszpasterzowania: „Są trzy stoły i na każdym z nich potrawa jemu właściwa. Pierwszy stół nauki [...] Drugi stół pokuty [...] Trzeci stół Eucharystii” (In festo Ss. Innocentium III 53-54). I dziś, po 750 latach, duszpasterstwo franciszkanów krakowskich, mimo jego wzbogacenia, przede wszystkim zastawia sobie i wiernym te 3 stoły: słowa Bożego, sakramentu pokuty i najświętszej Eucharystii.

\author{
EUCHARISTIC HERITAGE OF THE FRANCISCANS OF CRACOW \\ DURING THE TIME FROM THE 13TH TO THE 15TH CENTURY
}

\title{
Su m mary
}

The theme refers to the year 1987 as to the 750th anniversary of the Franciscans' coming to Cracow. It speaks of the medieval eucharistic spirituality inspired by St. Francis of Assisi, zealous executor of Lateran Council IV, and his contemporary St. Anthony of Padua, famous apologist of the Eucharist and St. Clare of Assisi, seraphic vestal virgin of the Blessed Sacrament. In addition to that, Cracow was reached to some measures by the Franciscan theology of the Eucharist, especially that of St. Bonaventure, also by the liturgical reform introduced by Haymon of Faversham, because the custodial monastery in Cracow, since its beginning, was the house of theological studies.

Since the very beginning, the life of the monastery was centered in the church named after St. Francis of Assisi, in its sanctuary at the altar of the Blessed Sacrament. There the friars performed their pastoral ministry setting for the faithful the three tables: of the Divine word, of the sacrament of Penance and of the Eucharist. The cult cherished here in the Middle Ages was the joint cult of the Suffering Christ and of Our Lady of Sorrow, of which the evidence is given by the ancient alter of „Mercy” and the mural painting of Jesus in the Mistic Press. In the 15th century, the Marian cult became distinct and centered at the picture of the Sorrowful Benefactress.

In 1438, upon the enlargement of the church and the cloisters, bp Zbignień Oleśnicki consecrated the new temple as Corpus Christi church which became the center of the solemn eucharistic cult in the town of Cracow. Later on it lost its spectacularity because of an influence of Protestantism and partly because of the growing popularity of the Observantines Friars (Bernardines) formed in 1453. Ad present the Franciscan basilica contains three centers: the main church for administering the sacraments of Penance and of the Eucharist, the Shrine of Our Lady of Sorrow, and the Chapel of Our Lord's Passion. Roots of all of them reach the Middle Ages. 